\title{
Estimation Of The Marshall-Lerner Condition For Namibia
}

\author{
Joel Hinaunye Eita, Monash University, South Africa
}

\begin{abstract}
According to the Marshall-Lerner condition, the sum of trade elasticities should be greater than one for a change in exchange rate to have an impact on the country's balance of payments. This paper applies cointegrated vector autoregression to empirically estimate the Marshall-Lerner condition in Namibia. The main purpose is to test the impact of change in exchange rate on the trade balance. The paper investigates if trade elasticities are high enough in order to justify a change in exchange rate as an appropriate policy to improve the trade balance of the balance payments. The results indicate that world income has a positive effect on exports, while real exchange rate appreciation discourages exports. Imports respond positively to both domestic income and real exchange rate appreciation. The results indicate that imports and exports respond significantly to a change in the exchange rate and suggest that Marshall-Lerner condition holds for Namibia.
\end{abstract}

Keywords: Trade Elasticities; Marshall-Lerner Condition; Namibia

\section{INTRODUCTION}

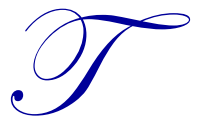

he issue of whether a change in exchange rate will improve the trading position of the country has remained central to the attention of policymakers for a long time. This idea was not only important during the gold standard period or fixed exchange rate regime. It still remains important to policymakers who expect that a change in exchange rate, such as depreciation, will promote their export industries. Policymakers are interested in the effects of relative price changes on trade flows. The conditions under which a devaluation or depreciation of currency can improve a country's trade balance is provided under the Marshall-Lerner condition.

Hegerty et al. (2012) describes the Marshall-Lerner condition as follows. A country's balance of trade is computed as exports minus imports. If a country's currency depreciates or is devalued, exports should increase and imports decrease and the balance of trade will improve. However, the balance of trade will improve only if exports and imports respond significantly to the change in exchange rate (devaluation or depreciation). This means that exports must increase and imports should also decrease in order to improve the trade balance of the balance of payments. According to the Marshall-Lerner condition, the summation of the import and export elasticities must be greater than one in absolute value for a depreciation or devaluation to improve the country's balance of trade.

There are many studies that tested the Marshall-Lerner condition for both developed and developing countries over the last 70 years. Some studies found evidence in support of the Marshall-Lerner condition. There are also studies which concluded that there was no evidence in support of the Marshall-Lerner condition. Empirical studies on trade elasticities or Marshall-Lerner condition in Namibia are scanty or non-existent. To the best of the author's knowledge, there is no empirical study on trade elasticities and the Marshall-Lerner condition for Namibia. The purpose of this paper, therefore, is to empirically estimate trade elasticities (Marshall-Lerner condition) for Namibia. 


\section{LITERATURE}

Empirical test of the Marshall-Lerner condition dates back to Robinson (1937) who explained the conditions under which a change in the exchange rate will improve the balance of trade. Robinson (1937) also estimated the corresponding elasticities. A concern was raised by Hirschman (1949) who argued that Robinson's estimation of these corresponding elasticities did not take into account trade that is denominated in foreign currencies. Despite this concern, the estimation of the corresponding elasticities by Robinson (1937) formed the foundation for various empirical analyses conducted over the last 70 years. The responsiveness of export and import to a change in the exchange rate is the kernel of the Marshall-Lerner condition. However, earlier empirical estimation of export and import elasticities did not pay much attention to the exchange rate in the specifications of their models. Hegerty et al. (2012) provides a summary of the studies conducted on the Marshall-Lerner condition over the last seven decades. The analysis shows that most studies used import and export price indexes and compared them to world price indices in order to test the Marshall-Lerner condition. Studies conducted after the 1960s began using relative price elasticities. For example, Houthakker and Magee (1969) tested the Marshall-Lerner condition using the following equations:

$$
\begin{aligned}
& \ln I M_{t}=\gamma_{0}+\gamma_{1} \ln Y_{t}+\gamma_{2} \ln \left(P I M_{t} / W P I_{t}\right)+\varepsilon_{t} \\
& \ln E X_{t}=\delta_{0}+\delta_{1} \ln W Y_{t}+\delta_{2} \ln (P E X / P X W)+\mu_{t}
\end{aligned}
$$

where $I M, E X, Y, W Y, P I M, P E X, P X W$ are imports, exports, domestic income or GDP (exporter's GDP), foreign income or GDP (importer's GDP), import price index, export price index and trading partner's (importer) prices. Equations (1) and (2) use relative price elasticities and these price ratios are taken as the exchange rate. Equations (1) and (2) were estimated for industrial and developing countries. Income and price elasticities were estimated, but this study (Houthakker and Magee, 1969) did not formally test the Marshall-Lerner condition. A foundation for reduced form estimation of trade elasticities was laid by Goldstein and Khan (1978), but this study focused only on export and did not test the Marshall-Lerner condition formally.

Wilson and Takacs (1979) estimated Equations (1) and (2) and separated the foreign and domestic price variables. A nominal exchange rate was added as additional explanatory variable. Their estimation also included trend and cyclical variables. This study estimated elasticities for advanced economies and importantly obtained the responsiveness of export and import to the exchange rate which is an important component of the Marshall-Lerner condition. This study also did not formally test the Marshall-Lerner condition and the relative price variables were also not included in their models.

Warner and Kreinin (1983) estimated import and export elasticities for 19 advanced economies for the period 1957 to 1970. They include the nominal exchange rate in their model specifications. However, this study focused on goals other than the Marshall-Lerner condition. The focus of this study was on the effects of introducing floating exchange rate and the role of expectations. Although this study estimated import and export elasticities, it did not test the Marshall-Lerner condition. Bahmani-Oskooee (1986) estimated the import and demand elasticities. The nominal exchange rate was included (in addition to income and relative prices) as one of the variables in both the import and export demand functions. Despite the fact that this study did not test the Marshall-Lerner condition, the results of this study indicated that the nominal exchange rate has an important effect on both imports and exports for all the countries in the sample. The export and import elasticities were estimated by Deyak et al. (1990) for the United States for the period 1958 to 1985, but both equations (import and export) did not include the exchange rate and relative prices. This study used a dynamic and polynomial distributed lag method to estimate export and import elasticities.

There are other studies which formally tested the Marshall-Lerner condition. Noland (1989) estimated the import and export elasticities for Japan and concluded that the Marshall-Lerner condition was satisfied. Arize (1987) estimated export and import elasticities for eight African countries using various specifications or variations 
of the supply and demand models (for import and export). The demand equation for export included variables such as trends in world income, import prices, world prices and lagged values of exports. The export supply equation included variables such as domestic income, unit values of exports, consumer price index, and lagged values of exports. These variables were also included in the import demand and supply equation. Import demand and supply equations were therefore estimated as functions of domestic and world GDP, price indices, and the lagged values of imports. The results indicated that the Marshall-Lerner condition was satisfied for the majority of the countries in the sample.

Reinhart (1995) used the dynamic ordinary least squares method to estimate import and export elasticities for 12 developing countries for the period 1968-1992. The results indicated that the Marshall-Lerner condition was met. They indicate further that African countries have elasticities that were large enough to meet the postulation of the Marshall-Lerner condition. A study by Prawoto (2007) on Malaysia, Thailand, Indonesia and Singapore produced mixed results. The results for Malaysia and Thailand were consistent with the prediction of the MarshallLerner condition. However, the results for Indonesia and Singapore did not conform to the Marshall-Lerner condition. A study by Sinha (2001) for five Asian countries (India, Japan, Philippines, Sri Lanka and Thailand) also confirmed that with the exception of Sri Lanka, the Marshall-Lerner condition was met for all countries. Razafimahefa and Hamori (2005) estimated import and export function for two African countries (Madagascar and Mauritius) and found that the results for Mauritius are in favour of the Marshall-Lerner condition. The results for Madagascar are not in support of the Marshall-Lerner condition.

Bahmani-Oskooee and Kara (2003) estimated export and import elasticities for 28 countries after the breakdown of the fixed exchange rate regime in the 1970s and the summation of import and export elasticities was greater than one. This suggests that there was evidence in support of the Marshall-Lerner condition.

\section{EMPIRICAL MODEL, ECONOMETRIC METHODOLOGY AND DATA}

\section{Empirical Model for Namibia}

Following and extensive review of the literature, this section discusses the empirical model to be estimated for Namibia. While many studies estimated export and import demand equations in the form of Equations (1) and (2), this study takes note that the exchange rate is the kernel of the Marshall-Lerner condition. The empirical models for Namibia are estimated as follows:

$$
\begin{aligned}
& \ln E X_{t}=\eta_{0}+\eta_{1} \ln W Y_{t}+\eta_{2} \ln R E R_{t}+\mu_{t} \\
& \ln I M_{t}=\beta_{0}+\beta_{1} \ln D Y_{t}+\beta_{2} \ln R E R_{t}+\varepsilon_{t}
\end{aligned}
$$

where $E X, I M, W Y, D Y$, and $R E R$ are exports of goods and services, imports of goods and services, world income, domestic income, and real effective exchange rate, and $\varepsilon$ and $\mu$ are the respective error terms. In Equation (3), an increase in world income is associated with an increase in exports. However, according to Bahmani-Oskooee and Kara (2003), an increase in world income can be associated with a decrease in exports. This can be possible if the increase in world income is attributed to an increase in import substitutes in the rest of the world; hence, $\eta_{1}>/<0$. An appreciation of the real effective exchange rate is expected to decrease the country's export which means that $\eta_{2}<0$.

It is expected that in Equation (4), an increase in domestic income will encourage imports and the elasticity will be positive; thus, $\beta_{1}>0$. An increase in domestic relative to foreign prices as proxied by appreciation of the real exchange rate makes domestic products less competitive and encourages imports. This will yield a positive elasticity and $\beta_{2}>0$. 


\section{Econometric Methodology}

Before the estimation of Equations (3) and (4), the time series properties of the variables, which involve unit root tests, need to be established. Many studies used the traditional unit root test statistics only (ADF and Phillips-Perron). These types of tests have low power and tend to under-reject the null hypothesis of unit root, even when the variable may be stationary. To address the shortcomings of these traditional unit root test statistics, this paper uses three tests to determine whether the variables to be used in the estimation are stationary or non-stationary. These tests are Augmented Dickey Fuller (ADF), Phillips-Perron (PP), and Kwiatkowski Phillips-Schmidt Shin (KPSS).

The paper uses a vector autoregression (VAR) model which has added benefits because it can model time series simultaneously. Using the vector error correction model (VECM) specification, this method corrects for autocorrelation and endogeneity parametrically (Johansen, 1988; 1995). This methodology has advantage over others, such as the Engle-Granger two-step procedure, because it prevents substantial bias that takes place in OLS estimates of cointegration relations. The Johansen econometric methodology is discussed as follows. The starting point in VAR of order $k$ is given by:

$y_{t}=\mu+B_{1} y_{t-1}+\ldots \ldots \ldots B_{k} y_{t-k}+v_{t}$

where $y_{t}$ is $(n \times 1)$ vector of variables. For each of $B_{i}$ is an $(n \times n)$ matrix of parameters, $v_{t}$ is a residual or $(n \times 1)$ vector of innovations. According to Sims (1980) this type of modelling estimates the dynamic relationships among variables that are jointly endogenous without the imposition of strong a priori restrictions. This is supported by Harris (1995). According to Harris (1995), Equation (5) can be re-specified in a VECM format as shown in Equation (6):

$\Delta y_{t}=\mu+\prod y_{t-1}+\sum_{j=1}^{k-1} \Gamma_{i} \Delta y_{t-i}+v_{t}$

where $\prod=\sum_{i=1}^{k} B_{i}-I$ and $\Gamma_{i}=-\sum_{j=i+1}^{k} B_{j}$.

According to Johansen $(1988 ; 1995)$, Equation (6) is a white noise and contains only variables that are stationary or I(0) because the terms in Equation (5) are all I(1). Harris (1995) argues that if the system is specified this way, there will be information on both short-run and long-run adjustment to changes in $y_{t}$ through $\prod$ and $\Gamma_{i}$ estimates. In the Johansen methodology and VAR analysis, $\prod$ is a vector representing a matrix of long-run coefficients. The long-run coefficients are defined as multiple of two ( $n \times r)$ vectors, $\alpha$ and $\beta^{\prime}$ (Harris, 1995). $\prod=\alpha \beta^{\prime}$, where the elements of $\alpha$ are called adjustment parameters in the VECM. They are loading matrices and represent the speed of adjustment from disequilibrium. The elements of $\beta^{\prime}$ are a matrix of long-run equilibrium such that the term $\beta^{\prime} y_{t}$ in Equation (6) represents up to $n-l$ economic equilibrium or cointegrating relationships in the model. If the $\prod$ has rank of zero, it means that there is no cointegration among variables in $y_{t}$. If the rank is $r$, there will $r$ possible stationary relationships. If the matrix has a full rank, the rank is $r=n$ and it suggests that there are $n$ cointegrating vectors and all variables in equation are $\mathrm{I}(0)$. There are two likelihood ratio tests proposed by Johansen (1988: 1995) for testing cointegration between variables. These are trace $\left(\lambda_{\text {trace }}\right)$ and maximum eigenvalue $\left(\lambda_{\max }\right)$ statistics. 


\section{Data}

The study uses annual data and covers the period 1991 to 2011. Export of goods and services (EX) and import of goods and services (IM) were obtained from the Bank of Namibia. The real effective exchange rate (RER) data were also obtained from the Bank of Namibia. Namibia's GDP is used as a proxy for domestic income (DY). The index of industrial production in industrial countries is used as a proxy for world income (WY). This is based on many studies in the relevant empirical literature.

\section{EMPIRICAL RESULTS}

\section{Unit Root Test}

The variables were tested for unit roots and the results of ADF, Phillips-Perron, and KPSS test statistics show that all variables are non-stationary in levels; they are I(1). The results of unit root tests are not presented here but can be obtained from the author upon request.

\section{Cointegration Test Results}

Cointegration test is the next step after establishing the unit roots test for the variables. The test is performed using two statistics, $\lambda_{\text {trace }}$ and $\lambda_{\max }$. The lag length for testing cointegration was based on the Akaike information criterion, Schwartz information criterion, Hannan-Quinn information criterion, log likelihood ratio and final prediction error. The lag length for the export equation was set at 1 , while that of the import equation was set at 2. Cointegration test results for the export equation are presented in Table 1. Table 2 presents the cointegration results for the import equation. Diagnostic statistics were performed on the unrestricted VAR and VECM, and show that residuals are multivariate normal and that no heteroscedasticity or serial correlation exists. The diagnostic statistics are not presented in the paper, but can be obtained from the author upon request. The $\lambda_{\text {trace }}$ and $\lambda_{\text {max }}$ test statistics identify one cointegrating vector for each equation.

Table 1: Cointegration Test Results For The Export Equation

\begin{tabular}{|c|c|c|c|c|c|c|c|}
\hline \multicolumn{3}{|c|}{ Trace Test } & \multicolumn{4}{c|}{ Maximum Eigenvalue Test } \\
\hline$H_{0}$ & $H_{a}$ & $\lambda_{\text {trace }}$ & $5 \%$ critical value & $H_{0}$ & $H_{a}$ & $\lambda_{\max }$ & $5 \%$ critical value \\
\hline $\mathrm{r}=0$ & $\mathrm{r} \geq 1$ & $25.80^{*}$ & 24.28 & $\mathrm{r}=0$ & $\mathrm{r}=1$ & $21.66^{*}$ & 17.80 \\
\hline $\mathrm{r} \leq 1$ & $\mathrm{r} \geq 2$ & 4.14 & 12.32 & $\mathrm{r}=1$ & $\mathrm{r}=2$ & 3.87 & 11.22 \\
\hline $\mathrm{r} \leq 2$ & $\mathrm{r} \geq 3$ & 0.27 & 4.13 & $\mathrm{r}=2$ & $\mathrm{r}=3$ & 0.27 & 4.13 \\
\hline
\end{tabular}

*Denotes rejection of the null of no cointegration at $5 \%$ significant level

Table 2: Cointegration Test Results For The Import Equation

\begin{tabular}{|c|c|c|c|c|c|c|c|}
\hline \multicolumn{3}{|c|}{ Trace Test } & \multicolumn{4}{c|}{ Maximum Eigenvalue Test } \\
\hline$H_{0}$ & $H_{a}$ & $\lambda_{\text {trace }}$ & $5 \%$ critical value & $H_{0}$ & $H_{a}$ & $\lambda_{\max }$ & $5 \%$ critical value \\
\hline $\mathrm{r}=0$ & $\mathrm{r} \geq 1$ & $25.80^{*}$ & 24.28 & $\mathrm{r}=0$ & $\mathrm{r}=1$ & $21.66^{*}$ & 17.80 \\
\hline $\mathrm{r} \leq 1$ & $\mathrm{r} \geq 2$ & 4.14 & 12.32 & $\mathrm{r}=1$ & $\mathrm{r}=2$ & 3.87 & 11.22 \\
\hline $\mathrm{r} \leq 2$ & $\mathrm{r} \geq 3$ & 0.27 & 4.13 & $\mathrm{r}=2$ & $\mathrm{r}=3$ & 0.27 & 4.13 \\
\hline
\end{tabular}

*Denotes rejection of the null of no cointegration at $5 \%$ significant level.

Evidence of cointegration suggests that it is now appropriate to proceed to the VECM. The VECM results for the export equations are presented in Table 3, while Table 4 presents those of the import equation. The first part (top) of each table contains long-run results while the second (lower) part represents short-run results.

Table 3 shows that an appreciation of the real exchange rate causes a reduction in exports. If real exchange rate appreciates by one percent, export will decrease by 0.44 percent. Increase in world income is associated with an increase in export. A one percent increase in world income causes export to increase by 2.87 percent. The coefficient of the error correction model is negative statistically significant which indicates that the dynamics adjust to long-run equilibrium. 
Table 3: VECM Results For The Export Equation

\begin{tabular}{|c|c|c|c|}
\hline Cointegrating Equation & Cointegrating Equation1 & & \\
\hline LNEX(-1) & 1.00 & & \\
\hline LNRER(-1) & 0.44 & & \\
\hline & {$[1.82]$} & & \\
\hline LNWY(-1) & -2.87 & & \\
\hline Error Correction Model: & $\Delta(11.24]$ & $\Delta$ (LNRER) & $\Delta($ LNWY) \\
\hline & -0.09 & -0.08 & -0.02 \\
Cointegrating Equation 1 & {$[-2.63]$} & {$[-1.05]$} & {$[-4.32]$} \\
\hline
\end{tabular}

Note: t-statistics are in square brackets.

Table 4 indicates that an increase in both real exchange rate and domestic income is associated with a rise in imports. An appreciation of the real exchange rate by one percent causes import to increase by 0.9 percent. If domestic income increases by one percent, import will increase by 1.56 percent. The coefficient of the error correction term is negative and statistically significant. This indicates that there is adjustment to equilibrium.

Table 4: VECM Results For The Import Equation

\begin{tabular}{|c|c|c|c|}
\hline Cointegrating Equation: & Cointegrating Equation 1 & \\
\hline LNIM(-1) & 1.00 & & \\
\hline & -1.56 & & \\
LNDY(-1) & {$[-11.18]$} & & \\
\hline LNRER(-1) & -0.90 & & \\
\hline C & {$[-3.70]$} & & $\Delta$ (LNDY) \\
\hline Error Correction Model: & $\Delta($ LNIM) & 0.16 & -0.20 \\
\hline Cointegrating Equation 1 & -0.17 & {$[3.19]$} & {$[-0.66]$} \\
\hline
\end{tabular}

Note: t-statistics are in square brackets.

The results in Table 3 and 4 are consistent with theoretical expectations and comparable with those obtained in the empirical literature. The kernel of estimating import and export elasticities is the Marshall-Lerner condition. The results indicate that the sum of import and export elasticities with respect to the exchange rate is greater than one $(0.90+0.44=1.34)$. This means that the Marshall-Lerner condition is met for Namibia. Exchange rate has a significant impact on exports and imports in Namibia

\section{CONCLUSION}

This study empirically estimated the Marshall-Lerner condition for Namibia. The study investigated the impact of world income, domestic income, and exchange rate on exports and imports. The study was conducted through an extensive review of the relevant literature. The results indicate that an increase in world income causes exports to increase. Real exchange rate appreciation makes domestic goods less competitive and hurts exports. The results also indicate that increase in domestic income and appreciation of the real exchange rate cause an increase in imports. The summation of import and export elasticities is greater than one which provides evidence that the Marshall-Lerner condition holds for Namibia. Changes in the exchange rate have significant impact on both imports and exports.

\section{AUTHOR INFORMATION}

Joel Hinaunye Eita, Ph.D. is an Associate Professor of economics at Monash University. His research interests include international trade and finance, financial and monetary economics, time series econometrics, macroeconometric modelling and panel data econometrics. He published in local and international journals. E-mail: joel.eita@monash.edu or hinaeita@yahoo.co.uk 


\section{REFERENCES}

1. Arize, A. (1987). The Supply and Demand for Imports and Exports in a Simultaneous Model, Applied Economics, 19: 1233-1247.

2. Bahmani-Oskooee, M. (1986). Determinants of International Trade Flows: The Case of Developing Countries, Journal of Development Economics, 20(1): 107-123.

3. Bahmani-Oskooee, M. and Kara, O. (2003). Relative Responsiveness of Trade Flows to a Change in Price and Exchange Rate, International Review of Applied Economics, 17(3): 293-308.

4. Deyak, T.A., Sawyer, W.C. and Sprinkle, R.L. (1990). The Effects of Exchange Rate Changes on Prices and Quantities in U.S. Foreign Trade, The International Trade Journal, 5(1): 77-92.

5. Goldstein, M. and Kahn, M.S. (1978). The Supply and Demand for Exports: A Simultaneous Approach, The Review of Economics and Statistics, 60(2): 275-286.

6. Harris, R.I.D. (1995). Using Cointegration Analysis in Econometric Modelling, London: Prentice Hall/Harvester Wheatsheaf.

7. Hegerty, S.C., Harvey, H. and Bahmani-Oskooee, M. (2012). Empirical Test of the Marshall-Lerner Condition: A Literature Review, Journal of Economic Studies, 40(3): 1-29.

8. Hirschman, A.O. (1949). Devaluation and the Trade Balance: A Note, The Review of Economics and Statistics, 31(1): 50-53.

9. Houthakker, H.S. and Magee, S.P. (1969). Income and Price Elasticities in World Trade, The Review of Economics and Statistics, 51(2): 111-125.

10. Johansen, S. (1995). Likelihood Based Inferences in Cointegrated Vector Autoregressive Models, Oxford: Oxford University Press.

11. Johansen, S. (1998). Statistical Analysis of Cointegrating Vectors, Journal of Economic Dynamics and Control, 12: $231-254$.

12. Noland, M. (1989). Japanese Trade Elasticities and the J-Curve, The Review of Economics and Statistics, 71(1): 175-179.

13. Orcutt, G.H. (1950). Measurement of Trade Elasticities in International Trade, The Review of Economics and Statistics, 32(2): 117-132.

14. Prawoto, R.B. (2007). On Trading Behaviour in Four Selected ASEAN Countries Before Monetary Crisis, Gadjah Mada International Journal of Business, 9(2): 273-290.

15. Razafimahefa, I.F. and Hamori, S. (2005). Import Demand Functions: Some Evidence from Madagascar and Mauritius, Journal of African Economies, 14(3): 411-434.

16. Reinhart, C.M. (1995). Devaluation, Relative Prices, and International Trade: Evidence from Developing Countries, IMF Staff Papers, 42(2): 290-312.

17. Robinson, J. (1937). Essays in the Theory of Employment, New York: Macmillan Company.

18. Sims, A. C. (1980). Macroeconomics and Reality, Econometrica, 48(1): 1 - 48.

19. Sinha, D. (2001). A Note on Trade Elasticities in Asian Countries, The International Trade Journal, 15(2): 221-237.

20. Warner, D. and Kreinin, M.E. (1983). Determinants of International Trade Flows, The Review of Economics and Statistics, 65(1): 96-104.

21. Wilson, J.F. and Takacs, W.E. (1979). Differential Responses to Prices and Exchange Rate Influences in the Foreign Trade of Selected Industrial Countries, The Review of Economics and Statistics, 61(2): 267279. 
NOTES 